\title{
Efektivitas Program Suplementasi Zat Besi pada Remaja Putri di Kota Bogor
}

\section{Effectiveness of Iron Supplementation Programme in Adolescent girl at Bogor City}

\author{
Tyas Permatasari*, Dodik Briawan, Siti Madanijah \\ Departemen Gizi Masyarakat, Fakultas Ekologi Manusia, Institut Pertanian Bogor \\ ('permatasari.tyas@gmail.com)
}

\begin{abstract}
ABSTRAK
Prevalensi anemia pada remaja putri masih tetap tinggi. Program suplementasi besi untuk remaja putri bertujuan menurunkan prevalensi anemia, tetapi hasilnya tidak selalu sukses. Penelitian ini bertujuan untuk melihat efektivitas program suplementasi besi pada remaja putri di Kota Bogor. Desain yang digunakan yakni quasi experiment pre-post intervensi pada study effectiveness. Penelitian berlangsung dari September 2016 sampai Januari 2017 bersama Dinas Kesehatan Kota Bogor. Jumlah subyek penelitian yakni 172 remaja putri usia (10-18 tahun) dari 4 sekolah. Pengambilan darah di ujung jari untuk menguji kadar hemoglobin subjek dianalisis menggunakan metode cyanmethemoglobin. Hasil penelitian menunjukkan prevalensi anemia $(\mathrm{Hb}<12 \mathrm{~g} / \mathrm{dl})$ sebelum program $20.7 \%$ dan menurun menjadi $15.2 \%$ setelah 4 bulan intervensi. Hasil analisis regresi logistik menunjukkan bahwa faktor yang mempengaruhi peningkatan kadar $\mathrm{Hb}$, yakni status $\mathrm{Hb}$ awal $(\mathrm{p}<0.05 ; \mathrm{OR}=3.52 ; \mathrm{CI} 95 \%=1.40-8.85)$. Program suplementasi besi pada remaja putri di Kota Bogor belum berjalan secara efektif.
\end{abstract}

Kata kunci : Anemia, efektivitas, remaja putri, suplementasi besi

\section{ABSTRACT}

Prevalence of anemia in adolescent girl was still high. The iron supplementation program for improving the iron status, but this program is not always successfully to reducing prevalence anemia. The objective was to analyzed factor that influenced succesfully of iron supplementation program at the adolescent girls. A quasi experiment pre-post intervention design was applied in female student at Bogor City between September 2016 until January 2017 run by the Health Office of Bogor City. A number of 172 adolescent girls (aged 10-18 years) participated in the study from 4 school in Bogor City. Blood was collected through fingerthick and analyzed with cyanmethemoglobin method. The result showed that prevalence of anaemia ( $\mathrm{Hb}<12 \mathrm{~g} / \mathrm{dl}$ ) was found to be $20.7 \%$ and decreased by $5.2 \%$ after four month of supplementation. The logistic regression analyses showed that status before supplementation was factor that affect improve of haemoglobin level $(p<0.05 ; O R=3.52 ; C 195 \%=1.40-8.85)$. The iron supplementation program in Bogor city did not effective.

Keywords : Anaemia, adolescent girls, effectiveness, iron supplementation 


\section{PENDAHULUAN}

Anemia merupakan masalah gizi mikro yang banyak terjadi di seluruh dunia terutama di negara berkembang yang diperkirakan terjadi pada $30 \%$ populasi penduduk dunia. Anemia banyak terjadi pada semua kelompok usia terutama pada remaja dan ibu hamil. Anemia pada remaja putri sampai saat ini masih cukup tinggi. Data Kemenkes tahun 2013 menunjukkan prevalensi anemia gizi pada kelompok usia remaja ( $\geq 15$ tahun) adalah $22.2 \%{ }^{1}$

Remaja putri (10-19 tahun) merupakan salah satu kelompok yang rawan mengalami anemia. Remaja putri merupakan generasi masa depan bangsa yang nantinya akan menentukan generasi berikutnya. Gerakan 1000 HPK mendukung upaya perbaikan gizi untuk meningkatkan mutu SDM generasi masa datang. Kegiatan 1000 HPK dibentuk dengan tujuan untuk perluasan dan percepatan perbaikan gizi di dunia dengan fokus pada 1000 hari sejak hari pertama kehamilan. Remaja putri secara langsung tidak disebutkan dalam 1000 HPK, namun status gizi remaja putri atau pranikah memiliki kontribusi besar pada kesehatan dan keselamatan kehamilan dan kelahiran, apabila remaja putri menjadi ibu. ${ }^{2}$

Salah satu upaya yang telah dilakukan pemerintah untuk mendukung gerakan 1000 HPK, khususnya dalam menanggulangi masalah anemia pada remaja adalah melalui pemberian suplementasi Tablet Tambah Darah (TTD) berupa zat besi $(60 \mathrm{mg} \mathrm{FeSO})$ dan asam folat $(0.25 \mathrm{mg})$. Pemerintah Indonesia sejak tahun 1997 telah merintis langkah-langkah baru dalam upaya mencegah dan menanggulangi anemia gizi pada Wanita Usia Subur (WUS) dengan mengintervensi lebih dini lagi yaitu sejak usianya masih remaja, dikarenakan intervensi yang dilakukan pada saat WUS anemia saat hamil tidak dapat mengatasi masalah anemia. Kelompok remaja putri merupakan sasaran strategis dari program perbaikan gizi untuk memutus siklus masalah agar tidak meluas ke generasi selanjutnya. ${ }^{2}$ Program pemerintah Indonesia yang fokus terhadap penanggulangan anemia remaja putri yakni Program Pencegahan dan Penanggulangan Anemia Gizi Besi (PPAGB) dengan sasaran anak Sekolah Menengah Pertama (SMP) dan Sekolah Menengah Atas (SMA) melalui pemberian suplementasi kapsul zat besi.
Penelitian PPAGB di Kabupaten Tasikmalaya pada siswi SMP dan SMA dirasa belum efektif. Pemberian dengan pola setiap satu minggu sekali dan 10 tablet saat menstruasi cenderung memiliki hasil tingkat kepatuhan konsumsi TTD yang rendah. Selain itu juga program serupa yang dilakukan di Bekasi pada siswi SMP dan SMK tidak meningkatkan kadar $\mathrm{Hb}$ setelah diberikan suplementasi. ${ }^{3}$ Upaya pemerintah dalam menanggulangi masalah anemia gizi tidak selalu berjalan dengan baik dan efektif. Penelitian Kheirouri menyebutkan bahwa selain ketersediaan tablet besi dan efek samping yang ditumbulkan oleh tablet, terdapat faktor lainnya yang dapat memengaruhi keefektifan program suplementasi besi yaitu dipengaruhi kualitas TTD, cara sosialisasi kepada remaja putri, peran orangtua, kerjasama stakeholder, serta pelatihan edukator. ${ }^{4}$

Program Pencegahan dan Penanggulangan Anemia Gizi Besi (PPAGB) tahun 2016 di Kota Bogor baru berjalan di tahun kedua. Program di tahun pertama (2015) masih belum berjalan secara efektif dan hanya melihat cakupan pemberian saja. Oleh karena itu, penelitian ini bertujuan mengkaji efektivitas program pemberian suplemen tablet tambah darah pada remaja putri di Kota Bogor.

\section{BAHAN DAN METODE}

Penelitian dilakukan menggunakan desain quasi experiment pre- post intervention pada study effectiveness. Intervensi berupa pemberian suplemen besi bentuk tablet $(60 \mathrm{mg}$ besi elemental dan $0.25 \mathrm{mg}$ asam folat) selama 16 minggu pemberian. Subjek diberi suplementasi besi dengan periode mingguan dan 10 tablet selama menstruasi. Total tablet yang harus dikonsumsi yakni sebesanyak 52 tablet. Penelitian dilakukan di Kota Bogor, Provinsi Jawa Barat. Pelaksanaan intervensi ini berlangsung selama empat bulan yaitu sejak bulan September sampai Januari 2017. Penelitian ini dilakukan bersamaan dengan Program Pencegahan dan Penanggulangan Anemia Gizi Besi pada Remaja Putri SMP dan SMA yang dilaksanakan oleh Dinas Kesehatan Kota Bogor. Penelitian ini telah mendapatkan persetujuan etik dari Komite Etik Penelitian Kesehatan Fakultas Kedokteran Universitas Indonesia No.62/UN2.F1/ ETIK/2017.

Populasi subjek dalam program suplemen- 
tasi zat besi adalah remaja putri berusia 11-18 dari SMP dan SMA di Kota Bogor yang mengikuti program pemberian TTD dari Dinas Kesehatan. Program ini dilaksanakan pada 2 SMP dan 2 SMA sederajat di Kota Bogor. Sekolah yang dipilih menggambarkan 6 kecamatan yang ada di Kota Bogor. Selain keterbatasan penelitian dan cakupan, pemilihan sekolah-sekolah ini dipilih berdasarkan kriteria: sekolah yang pro-aktif terhadap program dan berada di bawah puskesmas yang berada di salah satu kecamatan di Kota Bogor, dibawah puskesmas yang mempunyai kinerja cukup baik, tersedia laboratorium dan tenaga laboratorium untuk fasilitas pengambilan dan pemeriksaan darah dengan metode cyanmethemoglobin.

Pemilihan subjek untuk program ini adalah siswa kelas satu yang termasuk dalam penjaringan kesehatan oleh puskesmas yang membawahi. Kriteria inklusi pemilihan subjek pada program pencegahan dan penanggulangan anemia gizi besi pada remaja putri SMP dan SMA yakni siswa yang mengikuti penjaringan yang diadakan oleh puskesmas, mengikuti program PPAGB, bersedia mengikuti penelitian hingga selesai serta mendapatkan izin dari orangtua. Kriteria eksklusi subjek yaitu siswa pindah sekolah dan siswa sedang menjala- ni pengobatan pada penyakit infeksi atau penyakit yang kontraindikasi dengan pemberian tablet $\mathrm{Fe}$. Jumlah responden yang memenuhi kriteria inklusi dan menyelesaikan penelitian berjumlah 172 orang yang merupakan perwakilan masing-masing sekolah yang mewakili tiap kecamatan di Kota Bogor.

Analisis deksriptif dilakukan melalui pengkategorian data untuk menggambarkan sebaran variabel berdasarkan persen. Analisis bivariat untuk mengetahui hubungan antara variabel independen dan variabel dependen menggunakan uji korelasi spearman. Analisis multivariat untuk mengetahui faktor yang memengaruhi variabel dependen menggunakan uji regresi logistik. Penyajian data statistik dalam penelitian ini berupa tabel distribusi frekuensi, dan analisis multivariat.

\section{HASIL}

Sebaran subjek berdasarkan umur, status gizi dan uang saku ditunjukkan pada (Tabel 1). Umur subjek berkisar antara 12-17 tahun. Ratarata usia subjek adalah $15.08 \pm 1.47$ tahun. Sebagian besar subjek $(60.5 \%)$ berada pada batasan usia remaja pertengahan (middle adolescence) yaitu antara 15-17 tahun. Penilaian status gizi subjek menggunakan ukuran z-score indeks masa

Tabel 1. Karakteristik Responden

\begin{tabular}{cccc}
\hline Karakteristik & $\mathbf{n}$ & $\mathbf{\%}$ & Mean \pm SD \\
\hline Umur & & & \\
$<15$ tahun & 104 & 60.5 & $15.08 \pm 1.47$ \\
$\geq 15$ tahun & 68 & 39.5 & \\
Status gizi & & & $-0.16 \pm 1.25$ \\
Sangat kurus & 2 & 1.2 & \\
Kurus & 16 & 9.3 & \\
Normal & 122 & 70.9 & \\
Gemuk & 26 & 15.1 & $16651 \pm 6.64$ \\
Obesitas & 6 & 3.5 & \\
Uang saku & & & \\
\hline
\end{tabular}

Sumber: Data Primer, 2017

Tabel 2. Parameter Kadar Hb Sebelum dan Setelah Intervensi Suplementasi Besi

\begin{tabular}{lccc}
\hline \multicolumn{1}{c}{ Parameter } & Sebelum & Sesudah & p \\
\hline Rata-rata \pm SD (g/dl) & $12.85 \pm 1.24$ & $13.75 \pm 1.63$ & $0.00^{*}$ \\
Minimum-maximum (g/dl) & $8.70-16.60$ & $8.30-18.09$ & \\
Prevalensi Anemia (\%): & & & \\
$\quad<12 \mathrm{~g} / \mathrm{dl}$ & $36(20.9)$ & $27(15.7)$ & $0.00^{*}$ \\
$\quad \geq 12 \mathrm{~g} / \mathrm{dl}$ & $136(79.7)$ & $145(84.3)$ & \\
\hline
\end{tabular}

Sumber: Data Primer, 2017

${ }^{*}$ Berhubungan signifikan pada $\mathrm{p}<0.05$ 
Tabel 3. Asupan Zat Gizi dan (\%) AKG Sebelum dan Selama Suplementasi

\begin{tabular}{lcc}
\hline \multicolumn{1}{c}{ Zat Gizi } & $\begin{array}{c}\text { Sebelum } \\
\text { Mean } \pm \text { SD }\end{array}$ & $\begin{array}{c}\text { Selama } \\
\text { Mean } \pm \text { SD }\end{array}$ \\
\hline Protein & & \\
$\quad$ Asupan (g) & $26.29 \pm 11.31$ & $31.55 \pm 23.28$ \\
\%AKG & $42.82 \pm 18.86$ & $52.58 \pm 38.80$ \\
Zat Besi (Fe) & & \\
$\quad$ Asupan (mg) & $4.71 \pm 2.92$ & $5.98 \pm 5.93$ \\
\%AKG & $18.1 \pm 11.2$ & $23.00 \pm 22.81$ \\
\hline
\end{tabular}

Sumber: Data Primer, 2017

Tabel 4. Peubah Perubahan Kadar Hb

\begin{tabular}{lccc}
\hline \multicolumn{1}{c}{ Peubah } & $\mathbf{p}$ & OR & CI 95\% \\
\hline Hb Awal & $0.007^{*}$ & 3.52 & $(1.40-8.85)$ \\
Asupan Besi & 0.106 & 0.14 & $(0.01-1.50)$ \\
Asupan Protein & 0.144 & 1.95 & $(0.79-4.81)$ \\
Kepatuhan konsumsi TTD & 0.563 & 2.06 & $(0.17-23.98)$ \\
Status Gizi (Antropometri) & 0.732 & 1.63 & $(0.09-28.70)$ \\
Status Menstruasi & 0.952 & 1.03 & $(0.29-3.60)$ \\
Konstanta & 0.60 & 0.91 & \\
\hline
\end{tabular}

Sumber: Data Primer, 2017

*Berhubungan signifikan pada $\mathrm{p}<0.05$

tubuh berdasarkan umur (IMT/U). Rata-rata nilai Z-score IMT/U keseluruhan subjek yaitu $-0.16 \pm$ 1.25. Status gizi subjek sebagian besar $(70.9 \%)$ termasuk kategori normal. Terdapat subjek dengan status gizi sangat kurus (1.2\%), selain itu juga terdapat subjek tergolong obesitas (3.5\%) (Tabel 1).

Prevalensi anemia sebelum pemberian intervensi suplementasi sebesar $20.9 \%$ dari 172 subjek. Sebaran prevalensi anemia tingkat sedang $11.1 \%$ (4 subjek) dan anemia tingkat ringan $88.8 \%$ (32 subjek). Prevalensi anemia menurun menjadi $15.7 \%$ setelah program pemberian suplementasi besi yakni mengalami penurunan sebesar $5.2 \%$. Terdapat perbedaan yang signifikan antara prevalensi anemia sebelum dan sesudah intervensi $(p<0.05)$. Selain itu juga 79.7\% subjek mengalami peningkatan kadar $\mathrm{Hb}$ dengan rata-rata peningkatan sebesar $0.89 \pm 1.32 \mathrm{~g} / \mathrm{dl}$, rata - rata kadar $\mathrm{Hb}$ setelah diberikan suplementasi yakni $13.75 \pm 1.63$ g/dl. Hasil rata-rata kadar $\mathrm{Hb}$ baik sebelum maupun sesudah terdapat perbedaan yang signifikan $(p<0.05)$ (Tabel 2).

Status gizi merupakan salah satu faktor untuk menetapkan diagnosis anemia seseorang. Status gizi dibagi menjadi dua yakni status gizi antropometri dan status gizi besi. Hasil uji korelasi
Spearman menunjukkan bahwa status gizi antropometri berkorelasi positif terhadap peningkatan kadar $\mathrm{Hb}(\mathrm{p}<0.05 ; \mathrm{r}=0.15)$. Status gizi besi dapat diamati melalui status $\mathrm{Hb}$ awal sebelum diberikan suplementasi. Hasil uji korelasi spearman pada penelitian menunjukkan bahwa terdapat korelasi negatif antara status $\mathrm{Hb}$ awal dengan peningkatan kadar $\mathrm{Hb}(\mathrm{p}<0.05 ; \mathrm{r}=-0.206)$.

Subjek yang sudah mengalami menstruasi sebanyak $69 \%$ sedangkan yang belum mengalami menstruasi sebanyak $31 \%$. Status menstruasi tidak berkorelasi dengan peningkatan kadar $\mathrm{Hb}$ $(\mathrm{p}>0.05)$. Hasil tabulasi silang juga menunjukkan $83.2 \%$ subjek yang telah menstruasi lebih meningkatkan kadar $\mathrm{Hb}$ dibandingkan yang belum. Subjek dengan menstruasi diketahui mengalami menstruasi yang tidak teratur yakni 54.4\% subjek mengalami menstruasi setiap 2-3 bulan sekali.

Hasil penelitian menunjukkan konsumsi lauk hewani sangat rendah yakni rata-rata subjek mengonsumsi daging sapi, ayam, dan hati kurang dari 3-6 kali per minggu. Jenis pangan hewani yang masih sering dikonsumsi oleh sampel remaja adalah ikan rata-rata frekuensi 3-6 kali dalam seminggu dan telur dengan rata-rata konsumsi hampir setiap hari baik sebelum maupun selama 
intervensi. Konsumsi pangan hewani tidak berkorelasi dengan peningkatan kadar $\mathrm{Hb}(\mathrm{p}>0.05)$. Persentase AKG dari semua zat gizi sebelum maupun selama intervensi masih dalam kategori $<70 \%$ AKG. Asupan zat besi pada siswi tergolong sangat rendah jika dibandingkan dengan $\mathrm{AKG}$ yakni $26 \mathrm{mg} /$ hari, namun terjadi peningkatan dari 4.71 mg menjadi $5.98 \mathrm{mg}$ selama intervensi. Begitu juga dengan protein masih dalam kategori kurang dari kecukupan AKG yakni $72 \mathrm{~g} /$ hari. Hanya memenuhi sekitar 50\% AKG. Hasil uji korelasi spearman menunjukkan tidak terdapat korelasi antara zat gizi selama intervensi dengan peningkatan kadar $\mathrm{Hb}(\mathrm{p}>0.05)$.

Kartu yang terkumpul pada bulan pertama hanya 55\% yang mengumpulkan dari total subjek, dan hanya 33\% yang patuh dalam mengonsumsi TTD. Kartu kepatuhan pada bulan kedua hingga bulan keempat dijadikan satu dalam satu kartu, sehingga kepatuhan konsumsi TTD bulan kedua hingga bulan keempat dilaporkan dalam satu kartu. Dari total sasaran hanya $12 \%$ yang mengumpulkan kartu kepatuhan, dan hanya $28.6 \%$ yang patuh mengonsumsi TTD.

Determinan yang paling berpengaruh terhadap peningkatan kadar $\mathrm{Hb}$ pada penelitian ini adalah status $\mathrm{Hb}$ awal. Hasil uji regresi logistik, status $\mathrm{Hb}$ awal $(\mathrm{p}<0.05$; OR $=3.52$; CI 95\% $=1.40$ $8.85)$. Hal ini berarti subjek yang mengalami anemia sebelum pemberian suplementasi mempunyai peluang 3.52 kali lebih besar untuk meningkatkan kadar hemoglobin dibandingkan subjek yang tidak mengalami anemia.

\section{PEMBAHASAN}

Program Pencegahan dan Penanggulangan Anemia Gizi Besi (PPAGB) pada remaja putri merupakan salah satu upaya yang dilakukan oleh Dinas Kesehatan Provinsi Jawa Barat untuk menurunkan prevalensi anemia yang masih tinggi pada remaja putri yang pada akhirnya diharapkan dapat menurunkan prevalensi anemia pada ibu hamil. Kegiatan ini dilaksanakan oleh Dinas Kesehatan Kota Bogor dan Puskesmas Utama serta Puskesmas Pembantu di setiap kecamatan yang berada dibawah naungan Kota Bogor. PPAGB pada remaja putri ini dilakukan dengan pemberian TTD selama 4 bulan. Program Pencegahan dan Penanggulangan Anemia Gizi Besi (PPAGB) di
Kota Bogor baru berjalan di tahun kedua. Target penurunan prevalensi anemia pada tahun 2016 yakni prevalensi anemia menurun menjadi $8 \%$. Selain itu cakupan pemberian Fe pada remaja putri tingkat SMP dan SMA yakni 20\% dari total remaja yang ada. ${ }^{5}$ Program di tahun pertama masih belum berjalan secara efektif dan hanya melihat cakupan pemberian saja. PPAGB pada remaja putri ini berlangsung bersama dengan program penjaringan gizi di sekolah.

Indikator keberhasilan (outcome) dari program pelaksanaan pemberian TTD yaitu menurunnya prevalensi anemia pada kelompok sasaran. Indikator yang dapat digunakan untuk menilai keberhasilan suatu program yakni peningkatan kadar $\mathrm{Hb}$ dan perubahan status anemia. ${ }^{3}$ Anemia pada remaja putri di Kota Bogor tergolong pada tingkatan masalah kesehatan tingkat sedang. ${ }^{6}$ Program di Vietnam dinilai berhasil menurunkan prevalensi anemia dikarenakan program suplementasi ditambahkan dengan pemberian intervensi obat cacing serta diikuti edukasi kepada sasaran. ${ }^{7}$

Penelitian yang dilakukan Susanti di Kabupaten Tasikmalaya dengan program pemberian TTD secara mingguan dan 10 tablet selama menstruasi mengalami peningkatan kadar $\mathrm{Hb}$ sebanyak $0.48 \pm 1.04 \mathrm{~g} / \mathrm{dl} .{ }^{8}$ Program serupa yang dilakukan pada wanita usia subur di Vietnam mengalami peningkatan kadar $\mathrm{Hb}$ selama 3 bulan intervensi yakni rata-rata meningkat sebesar $9.6 \mathrm{~g} / \mathrm{dl} .{ }^{7}$ Berbeda halnya dengan program suplementasi besi yang dilakukan di Kota Bekasi pada siswi SMP dan SMA, tidak terjadi peningkatan kadar $\mathrm{Hb}$ setelah diberikan suplementasi. ${ }^{3}$

Status gizi merupakan salah satu faktor untuk menetapkan diagnosis anemia seseorang. Status gizi dibagi menjadi dua yakni status gizi antropometri dan status gizi besi. Subjek dengan status gizi yang baik cenderung memiliki status kesehatan yang baik, fungsi dalam tubuh normal sehingga produksi hemoglobin juga akan lebih meningkat saat konsumsi Fe juga meningkat. ${ }^{9}$ Penelitian Permaesih dan Herman menunjukkan bahwa remaja yang mempunyai Indeks Massa Tubuh (IMT) kurang atau tubuh kurus mempunyai risiko 1.5 kali untuk menjadi anemia. ${ }^{10}$ IMT mempunyai korelasi positif dengan konsentrasi hemoglobin yang artinya jika seseorang memiliki IMT kurang maka akan berisiko menderita anemia. ${ }^{10}$ Peneli- 
tian lain yang dilakukan pada remaja putri di India menunjukkan hasil yang berbeda yakni IMT tidak berkorelasi dengan kejadian kadar hemoglobin. ${ }^{11}$

Status besi awal dapat memengaruhi sistem metabolisme zat besi. ${ }^{3}$ Subjek yang pada awalnya mengalami anemia dapat meningkatkan penyerapan $40 \%$ lebih cepat dibandingkan subjek yang tidak mengalami anemia. ${ }^{12}$ Sejalan dengan penelitian Briawan mengungkapkan bahwa perubahan kadar hemoglobin dipengaruhi oleh status $\mathrm{Hb}$ awal. ${ }^{13}$

Anemia pada remaja putri disebabkan masa remaja adalah masa pertumbuhan yang membutuhkan zat gizi lebih tinggi termasuk zat besi. Selain itu pada masa remaja, seseorang akan mengalami menstruasi. Status menstruasi dinilai dari subjek yang sudah mengalami atau belum menstruasi sehingga akan memengaruhi perubahan kadar hemoglobin. Anemia berhubungan signifikan dengan wanita yang mengalami menstruasi secara teratur dibandingkan yang tidak teratur. ${ }^{14}$

Sedikitnya kartu yang terkumpul disebabkan oleh faktor internal maupun eksternal, yakni dari sasaran dan motivasi dari luar. Alasan kartu tidak dikumpulkan yakni kartu yang diberikan hilang, terkena hujan, siswa malas mencatat serta mengganggap program pemberian TTD ini tidak penting. Hal yang sama terjadi pada penelitian Priya beberapa siswa (16\%) yang telah mengonsumsi mengaku tidak merasakan dampak postif dari konsumsi tablet. ${ }^{15}$ Selain itu juga, kurangnya pemantauan dan pengecekan dari guru ataupun orangtua. Pentingnya edukasi oleh guru terhadap pemantauan konsumsi TTD berpengaruh terhadap keberhasilan program. ${ }^{4}$ Upaya menurunkan prevalensi anemia dengan tingkat kepatuhan yang tinggi dipengaruhi kerjasama yang baik antar berbagai pihak yakni salah satunya guru dan orang tua. ${ }^{4,15}$

Rendahnya pengawasan dan motivasi dari pengkonsumsi TTD di rumah membuat tingkat kepatuhan rendah. Program pemberian TTD di India pada penelitian Risonar menunjukkan hasil kepatuhan yang cukup tinggi yakni didapatkan nilai kepatuhan $100 \%$ pengonsumsian TTD. ${ }^{16}$ Kepatuhan ditunjukkan dengan pengonsumsian secara langsung dengan edukasi dan pengawasan dari guru saat di sekolah dan dilakukan minum TTD bersama di hari yang telah ditetapkan.

Hasil penelitian ini sejalan dengan peneli- tian pada siswi di Tasikmalaya yakni asupan besi hanya sekitar $4.2-5.2 \mathrm{mg} /$ hari. $^{17}$ Demikian pula pada penelitian di Makasar hampir seluruh subjek kurang dari AKG yakni sebanyak 94\% tidak cukup asupan zat besi. ${ }^{18}$ Sejalan dengan penelitian Briawan bahwa \% AKG protein maupun besi tidak berpengaruh terhadap perubahan kadar hemoglobin. ${ }^{19}$

Peningkatan kadar $\mathrm{Hb}$ yang dimaksud dalam hal ini adalah peningkatan dari rata-rata yakni sebesar $\geq 0.89 \mathrm{~g} / \mathrm{dl}$ setelah intervensi. Peubah yang dianalisis untuk menentukan faktor yang memengaruhi peningkatan kadar $\mathrm{Hb}$ adalah status $\mathrm{Hb}$ awal, status menstruasi, status gizi antropometri, \% AKG protein dan \% AKG besi serta tingkat kepatuhan. Faktor yang paling berpengaruh terhadap peningkatan kadar $\mathrm{Hb}$ pada penelitian ini adalah status $\mathrm{Hb}$ awal. Banyak studi menunjukkan bahwa subjek yang anemia akan lebih responsif di dalam peningkatan hemoglobin, cadangan besi yang kurang (depleted) dapat menyebabkan perbaikan biomarker yang lebih baik dibandingkan subjek yang tidak mengalami deplesi besi. ${ }^{20,21}$ Hasil studi eksperimental mengenai suplementasi besi menunjukkan bahwa perubahan kadar $\mathrm{Hb}$ hanya dipengaruhi oleh $\mathrm{Hb}$ awal. ${ }^{19}$ Peubah perancu seperti serum ferritin (SF), serum transferrin receptor (STfR), Hb, IMT, kepatuhan, \% AKG energi, protein, vitamin $\mathrm{A}$, vitamin $\mathrm{C}$, zat besi tidak berpengaruh signifikan pada perubahan $\mathrm{Hb}$.

Program PPAGB di Kota Bogor berhasil menurunkan anemia, namun masih jauh dari target yang ditetapkan oleh Bapeda Bogor yakni anemia menurun menjadi $8 \%$. Program masih dinilai belum berjalan maksimal secara menyeluruh di masing-masing bagian. Kepatuhan konsumsi tablet tambah darah juga masih sangat rendah, hal ini juga menjadikan program dinilai menjadi belum efektif. Efektivitas suatu program dapat dipengaruhi oleh tingkat kepatuhan dan proses pada pelakasanaan program yang berhubungan dengan kebiasaan seperti biaya pelakasanaan, ketersediaan dan faktor lainnya. ${ }^{22}$ Studi efektivitas program di Indonesia khususnya terkait anemia masih belum banyak dilakukan, sebagian besar hanya terkait efikasi anemia pada prevalensi anemia. Oleh karena itu, diperlukan studi lanjutan yang lebih mendalam terkait efektivitas program anemia. 


\section{KESIMPULAN DAN SARAN}

Prevalensi anemia pada subjek remaja putri mengalami penurunan setelah diberikan intervensi. Faktor yang paling berpengaruh terhadap peningkatan kadar $\mathrm{Hb}$ pada penelitian ini adalah status $\mathrm{Hb}$ awal. Program PPAGB dinilai masih belum efektiv, meskipun terjadi penurunan prevalensi tetapi angka kepatuhan dari konsumsi TTD masih rendah.

Saran untuk program yakni program pemberian TTD selanjutnya bisa dilakukan dengan cara minum TTD bersama pada hari yang sudah ditentukan agar mengurangi alasan siswa untuk lupa mengonsumsi serta selalu meletakkan kartu kepatuhan di rak kelas di sekolah. Selain itu juga, sosialisasi konsumsi TTD bisa dilakukan pada orangtua siswa agar siswa mendapat dukungan dan orangtua memahami pentingnya mengonsumsi TTD serta menyediakan makanan yang kaya akan zat besi khususnya lauk hewani yang masih jarang dikonsumsi oleh subjek (daging sapi, daging ayam, hati dan ikan). Saran untuk sasaran program yakni fokus sasaran program pada remaja putri yang mengalami anemia lebih diutamakan. Kepatuhan mengonsumsi TTD sangat rendah dari program TTD pada remaja putri, motivasi dan dukungan baik dari orangtua dan guru sangat penting dilakukan. Edukasi dan pelatihan terhadap guru oleh petugas kesehatan terkait pentingnya program TTD dan penatalaksanaan program TTD sangat penting dilakukan. Saran untuk penelitian selanjutnya yakni dapat diberikan perbandingan kontrol terhadap study effectivenes program PPAGB.

\section{UCAPAN TERIMA KASIH}

Penulis mengucapkan terima kasih dan penghargaan kepada Dinas Kesehatan Kota Bogor yang telah mengizinkan penelitian dengan hasil yang dapat digunakan untuk publikasi bersama.

\section{DAFTAR PUSTAKA}

1. Kemenkes RI. Hasil Riset Kesehatan Dasar 2013. Jakarta : Badan Penelitian dan Pengembangan Kesehatan; 2013.

2. Bapenas RI. Kerangka Kebijakan: Gerakan Sadar Gizi dalam Rangka Seribu Hari Pertama Kehidupan (1000 HPK). Jakarta : Badan Perencanaan dan Pembangunan Nasional; 2012.
3. Briawan D, Adriyani A, Pusporini. Determinan Keberhasilan Program Suplementasi Zat Besi pada Siswi Sekolah. Jurnal Gizi Klinik Indonesia. 2009;6(2):78-83.

4. Kheirouri S, Alizadeh M. Process Evaluation of A National School-Based Iron Supplementation Program for Adolescent Girls in Iran. BMC Public Health. 2014;14:959.

5. Bappeda. Rencana Pembangunan Jangka Menengah Daerah. Bogor: Badan Perencanaan dan Pembangunan Daerah; 2015.

6. WHO. Iron Deficiency Anaemia Assessment, Prevention and Control. A Guide for Programmed Managers. Geneva: World Health Organization; 2001.

7. Casey GJ, Phuc TQ, MacGregor L, Montresor A, Mihrshahi S, Thach TD, Nong Tien, Biggs Beverley-Ann. A Free Weekly Iron-Folic Acid Supplementation and Regular Deworming Program is Associated with Improved Hemoglobin and Iron Status Indica Tors in Vietnamese Women. BMC Public Health. 2009; 9:261.

8. Susanti Y, Briawan D, Martianto D. Suplementasi Besi Mingguan Meningkatkan Hemoglobin Sama Efektif dengan Kombinasi Mingguan dan Harian pada Remaja Putri. J. Gizi Pangan. 2016;11(1):27-34.

9. Mahan LK, Raymond JL. Krause's Food and The Nutrition Care Process. Missouri: Elsevier; 2017.

10. Permaesih D, Herman S. Faktor-Faktor yang Memengaruhi Anemia pada Remaja. Bul Penel Kes. 2005;33(4):162-171.

11. Kaur M, Singh A, dan Bassi R. Nutritional Status and Anaemia in Medical Students of Sgrdimsar, Amritsar. National Journal of Physiology, Pharmacy \& Pharmacology. 2015;5(1):35-49.

12. Brown JE. Nutrition Through The Life Cycle. Wadsworth: Cengage Learning; 2011.

13. Briawan D. Efikasi Fortifikasi Cookies Ubi Jalar untuk Perbaikan Status Anemia Siswi Sekolah. Majalah Kesehatan Bandung. 2013; 45(4):206-12.

14. Rati SA, Jawadagi S. Prevalence of Anemia Among Adolescent Girls Studying in Selected Schools. International Journal of Science and Research. 2014;3(8):1237-1242. 
15. Priya S, Datta SS, Baharupi BS, Narayan KA, Anbarasan N, RM Ramya. Factors Influencing Weekly IFA Supplementation Programme (WIFS) Among School Children: Where to Focus our attention?. International Journal of Contemporary Medical Research. 2016;3:(4).

16. Risonar MGD, Tengco LW, Rayco SP, \& Solon FS. The Effect of A School-Based Weekly Iron Supplementation Delivery System Among Anemic School children in The Philippines. Eur J Clin Nutr. 2008;62:991-996

17. Susanti, Yeti. Pengaruh Pemberian Suplemen Besi terhadap Kadar Hemoglobin dan Tingkat Kelelahan pada Remaja Putri [Tesis]. Bogor: Institut Pertanian Bogor;2016.

18. Rahayu I. An Examination of The Eating Behaviour of Adolescent Girls in Indonesia: Formative Research for Prevention of Iron Deficiency [Disertasi]. Brisbane: The University of Queensland;2011.

19. Briawan D, Hardinsyah, Setiawan B, Marliyati SA, dan Muhilal. Efikasi Suplemen Besi-Multivitamin untuk Perbaikan Status Besi Remaja Wanita. Jurnal Gizi Kesehatan Indonesia. 2008;30(1):30-36.

20. Beard JL, Dawson H, \& Pinero DJ. Iron Metabolism: A Comprehensive Review. Nutr Rev. 1996;54(10):295-317

21. Allen LH. Iron Supplementation: Scientific Issues Concerning Efficacy and Implications for Research and Programs. J Nutr. 2002; 132(4):813S-819S.

22. Davidsson L \& Nestel P. Efficacy and Effectiveness of Interventions to Control Iron Deficiency and Iron Deficiency Anemia. The International Nutritional Anemia Consultative Group (INACG). 2004. 